\title{
Does Auditor Rotation Increase Auditor Independence?
}

\author{
Junaidi, Jogiyanto Hartono, ${ }^{2}$ Eko Suwardi, ${ }^{2}$ Setiyono Miharjo, ${ }^{2}$ and Bambang Hartadi ${ }^{1}$ \\ 1) Faculty of Informatics Technology and Business, Universitas Teknologi Yogyakarta, Indonesia; \\ ${ }^{2)}$ Faculty of Economics and Business, Universitas Gadjah Mada, Indonesia
}

\begin{abstract}
This study aims to empirically test the effects of auditor rotation and auditor tenure on an auditor's independence in companies listed on the Indonesia Stock Exchange during the years 2002-2010. This study using logistic regression estimation technique. The results show that, statistically, the auditor's tenure has significant negative effects on the auditor's independence, measured by the tendency to give a 'going concern' opinion. Furthermore, the results also show significant differences between the effects of short and long term tenures on the auditors' independence. Auditor rotation has significant positive effects on the auditors' independence.
\end{abstract}

Abstrak: Penelitian ini bertujuan untuk menguji secara empiris pengarub rotasi auditor dan masa kerja auditor terhadap independensi auditor pada perusahaan yang listed di Bursa Efek Indonesia selama tabun 2002-2010. Penelitian ini menggunakan teknik estimasi regresi logistik. Hasil penelitian menunjukkan bahwa secara statistik, masa kerja auditor berpengaruh signifikan negatif terbadap independensi auditor yang diukur dengan kecenderungan memberikan opini 'berkelanjutan.' Hasil penelitian juga menunjuk.kan perbedaan signifikan antara pengaruh masa kerja auditor yang pendek dan lama pada independensi auditor. Rotasi auditor berpengarub positif signifikan terbadap independensi auditor.

Keywords: audit quality; going concern; independence; rotation; tenure

JEL classification: M42

* Corresponding author's e-mail: masjoen@uty.ac.id 


\section{Introduction}

This study empirically re-tests the effect of rotating auditors on the independence of auditors, in relation to the phenomenon of the artificial rotation of auditors in Indonesia, before the appearance of the newest regulation on partners' (public accountants) rotation. The results of the empirical study show different outcomes on whether or not the mandatory auditor rotation is important. Geiger and Raghunandan (2001), Myers et al. (2003), Johnson et al. (2002) state that auditing and financial reporting, and auditors' tenure are passively related, so that the results of the research do not support the existence of mandatory auditor rotation. Daugherty et al. (2013), Johnson et al. (2002), Siregar et al. (2011) do not find evidence that rotating auditors increases the quality of financial reports.

In Indonesia, the regulation about mandatory auditor and partner rotation has faced some alterations. The regulation began with the Decree of the Minister of Finance No.423/KMK.06/2002 which was superseded by No.359/KMK.06/2003, that obliges companies to limit an auditor's assignment period to 5 years and a public accountant's to 3 years. That decree then was revised by the Decree of the Minister of Finance No.17/ PMK.01/2008 about public accountants' service which limited the auditor's assignment period to 6 years and the public accountant's to 3 years. On April 6, 2015 the government published Government Regulation No.20 of 2015 about Public Accountants' Practices (PP 20/2015) which is a further regulation of Law No.5 of 2011 about public accountants. In relation to the regulation of public accountants' service rotations, it is written in Article 11 PP 20/2015, Article 11 Verse (1) which explains that: The service of au- diting of historical financial information, as meant in Article 10 Verse (1) letter "a", of any certain entity by a public accountant is limited to 5 (five) years financial records in succession.

Furthermore, this research also tests whether the artificial rotation of auditors can influence the auditors' independence. Mautz and Sharaf (1961) state that an auditor must be aware of a lot of conditions which may tend to influence their attitude and independence. On one side, an auditor's tenure is related to the high professionalism that is obtained by the auditor, in this case, from a long tenure, because the auditor may get a better understanding about the business' processes and the risks facing the client's company. On the other hand, an auditor's tenure is related to the lower awareness of the auditor, because of the over-familiarity between the auditor and the client (Mautz and Sharaf, 1961).

The importance of auditor independence encourages the regulator to regulate the length of an auditor's assignment period in order to improve independence. However, the empirical findings which show the effects of auditors' tenure and rotation on the audits' quality have not been conclusive. Some research shows that tenure has negative influences on an audit's quality (Mansi et al. 2004; Nagy 2005; Mai et al. 2008; Coram et al. 2008; Giri 2011). On the other hand, other research does not support the claims that tenure has negative influences on the quality of the audit (Geiger and Raghunandan 2002; Myers et al. 2003; Ghosh and Moon 2005). Furthermore, whether or not auditor and partner rotation is important is still debatable. The studies on auditor rotation are related to the audit's fee, financial report's quality, and audit's quality (Daugherty et al. 2013; Johnson et al. 2002; Siregar et al. 2011) do 
not find that auditor rotation improves the quality of financial reports. Yet, Geiger and Raghunandan (2002), Knechel et al. (2007) show that auditor rotation has negative influences on financial reports and audits' qualities.

Artificial rotation is a condition in which, conceptually, there has been a change of auditor so that the relationship between the audit firm and the client ends, but in fact such a relationship is still ongoing (Junaidi et al. 2012). Tenure is suspected of breaking the auditor's independence, since over a long time period there may be over-familiarity between the client and the auditor (Mautz and Sharaf, 1961). Deis and Giroux (1992), Mansi, et al. (2004), Nagy (2005), Mai, et al. (2008) state that tenure has negative effects on audits' qualities. Coram et al. (2008) finds evidence that, probably, to maintain their clients, auditors tend to lower the standards expected of a professional public accountant. In contrast, Geiger and Raghunandan (2002), Myers et al. (2003), Ghosh and Moon (2005) reject the statement that tenure brings negative effects to an audit's quality.

Conflict of interests is suspected to be a factor in the audit quality's degradation. Carrera et al. (2007) shows that more than half of all the auditor-client negotiations really influence the audit reports. Dharmasaputra and Nafi (2007) state that Enron's financial reporting scandals in 2001 were proven to encourage many countries to strengthen their regulations on auditors and their partners. However, whether or not mandatory auditor rotation is important has since been debatable. According to Dharmasaputra and Nafi (2007), most of the other countries consider that such a regulation is less important, because there are only a few countries adopting such regulations, including Indonesia.
Some research in America does not support the idea that the duration of the relationship between the auditor and client has a negative influence on the audit's quality (Ghosh and Moon 2005, Myers et al. 2003, Geiger and Raghunandan 2002). Geiger and Raghunandan (2002) state that the errors in audits' reports are significantly more prevalent at the beginning of a relationship between the auditor and client. Ghosh and Moon (2005) find that the perception of investors towards the quality of profits will increase when the auditor's tenure is longer. Carcello and Nagy (2004) find the evidence that cheating in financial reporting is more likely to happen in the first three years of an auditor's tenure. Shafie et al. (2009), who did their research in Malaysia, shows that auditors' tenure has significant positive effects on the quality of the auditors' reports.

Meanwhile there is some research which proves that auditors' tenure brings negative effects to the audit's quality (Mai et al. 2008; Nagy 2005; Mansi et al. 2004; Junaidi 2012). Johnson et al. (2002) do not find evidence that auditor rotation, when done to anticipate an auditor's tenure, increases the quality of the financial reports. Hartadi (2009) finds that audit fees significantly influence the audit's quality, while auditor rotation and the auditor's reputation do not significantly influence the audit's quality which is measured by its total accrual. Giri (2011) finds that tenure has negative effects on the audit's quality, while the auditor's reputation has no effect on it. However, Siregar (2011) finds that there is no evidence that the duration of the auditor's tenure and auditor's rotation increase the audit's quality.

Auditor independence will be tested when the auditor's firm is placed in a situation when they have to give their opinion about their client's financial reports. The In- 
donesian Accountants' Association (2001), which has now become the Institute of Indonesian Public Accountants, has adopted auditing standards related to the assumption of 'going concerns' that has been regulated in the United States of America by the Statement on Auditing Standards (SAS) No. 59: The auditor's considerations of an entity's ability to continue as a 'going concern' SAS No. 59 (AICPA, 1988) requires the auditor to evaluate whether there is a substantial hesitancy regarding the professionalism of the client's company to go on as a 'going concern.'

To give an audit opinion about companies where the professionalism of their sustainability is questionable is not an easy job. The decision about a 'going concern' is a very difficult and ambiguous one (Chow et al. 1987; Carmichael and Pany 1993; Carcello and Neal 2000). When the auditor has decided that there is a substantial hesitancy about the client's sustainability, the auditor is allowed to give an unqualified modified report, or even a disclaimer. Yet, almost no authoritative guidance or research has been published that an auditor can use to decide which type of published 'going concern' reports to issue (Lasllae and Anandarajan 1996).

\section{Theory and Hypothesis Development}

\section{Audit Quality}

DeAngelo (1981a) states that an audit's quality contains 2 elements, the auditor's competency and independency. Competence means that auditing must be done by those who have the skills and have completed some qualified technical training. Independence, in terms of an audit, means the auditor takes a non-biased viewpoint when carrying out the audit, evaluating the results, and making the audit's report. Coram et al. (2008) state that the quality of an audit is shown by the probability of the auditor finding unintentional/ intentional errors in companies' financial reports, and the probability of the findings being reported in and attached to the audit's opinion. Furthermore, Peecher and Piercey (2008) state that an audit's quality is the probability of an auditor finding and reporting violations found in the client's accounting system. The probability of the discovery of a violation depends on the technical professionalism and independence of the auditor.

\section{The Concept of Independency}

Independency is a mental attitude possessed by auditors to stop them from taking sides when auditing (Mautz and Sharaf 1961). Audit service users see that the auditor's independence from the financial reports is present when the reports from the compiler and the users are being audited. Independence is a component of professionalism which has to be maintained by professional public accountants. Independence, in this case, is that public accountants prioritize the public's needs above the clients or auditors' interests when auditing the financial reports of the clients. Thus, in this case, the stance of the auditor is likely to be to prioritize the public's needs.

\section{Audit Standards in Indonesia for 'Going Concern'}

PSA No. 30 and SA Section 341 (IPSA 30.01) provide guidance to auditors, regarding the impact of the ability of the business unit to continue to function in the auditor's opinion as follows: 
a. If the auditor believes that there are doubts about the ability of the business unit to survive for a reasonable period of time, the auditor should:

1. Obtain information about the management's plans to reduce the impact of conditions and events.

2. Establish the possibility that such a plan is effectively implemented.

b. If the management does not have a plan to reduce the impact of conditions and events on the ability of the business unit to survive, the auditor should consider making a statement of intent to not give any opinion.

c. If the management has a plan, the next step is for the auditor to consider the effectiveness of the plan, as follows:

1. If the auditor finds no effective plan, the auditor must express no opinion.

2. If the auditor finds the plan is effective and the client expresses these circumstances in the notes of the financial statements, the auditor expresses an unqualified opinion.

3. If the auditor finds the plan is effective but the client does not disclose the circumstances in the notes of the financial statements, the auditor expresses an unfair opinion.

Furthermore, the Institute of Indonesian Public Accountants (2009) published the Interpretation of the Statements for Standard Auditing (IPSA 30.02) as a replacement for PSA 30, which aims to provide interpretation, clarification, and further guidance to the auditors when applying the PSA 30 regulation on the auditor's judgment about a company's ability to maintain its viability.

\section{Auditor Tenure and Audit Quality}

Auditor tenure shows the duration of the relationship between an auditor and client. Some research that has uncovered the relationship between tenure and audit quality includes works by Geiger and Raghunandan (2002), Johnson (2002), Myers et al. (2003), Manry, et al. (2003), Carcello and Nagy (2004), Ghosh and Moon (2005), Carey and Simnett (2006), Knechel and Vanstraelen (2007), Shafie et al. (2009), AlThuneibat et al. (2010). Most of the research in America rejects the statement that the duration of the relationship between an auditor and client brings negative effects to an audit's quality (for example like Geiger and Raghunandan 2002; Myers et al. 2003; Carcello and Nagy 2004; and Ghosh and Moon 2005).

Carey and Simnett (2006) state that there are two main arguments that support the negative associations of an auditor's long tenure and audit quality which are: (1) The degradation of independence which may be caused by the intensity of the personal relationship between the auditor and the client; and (2) the deterioration in the audit partner's capacity to effect critical appraisal (described in the IFAC Code of Ethics as familiarity threat. The development of a personal relationship between the management of the client company and the auditor will threaten the auditor's independence. Davis et al. (2000) explain that the supporters of auditor rotation contend that such rotation will provide 'a new appearance' for the company's financial information. They claim that the longer an auditor tries to keep a client, the less the auditor maintains their objectivity when assessing the client's statements, and the greater is the possibility that there will be undetected errors in the financial reports. 
Carey and Simnett (2006) show that there is a negative significant relationship between audit partners' tenure and the audit's quality, and auditors will have a lesser tendency to give a 'going concern' opinion in a long tenure observation. Knechel and Vanstraelen (2007) show that an auditor's decision about a 'going concern' opinion is not influenced by tenure, in a sample of bankrupt companies, while in a sample of 'still in business' companies they find some evidence of a negative relationship between an auditor's tenure and giving a 'going concern' opinion. Moreover they also state that the evidence of whether the length of the tenure increases or decreases the quality is weak.

Longer auditor tenures may be related to the loss of awareness through over-familiarity with the client (Mautz and Sharaf, 1961). Long auditor tenures can create economic benefits for the auditor to become less independent, in this case an auditor can bow to the client's pressure, in order to maintain future audit fees (Hoyle, 1978). Davis et al. (2002), Ghosh and Moon (2005), and AlThuneibat et al. (2011) conclude that an audit's quality decreases as the duration of the tenure grows. Based on the concept and results of the research which are revealed, a hypothesis can be postulated as follows:

Hypothesis 1: Auditor tenure has negative effects on the auditor's independence.

\section{Auditor Rotation and Audit Quality}

The research by Geiger and Raghunandan (2002), Myers et al. (2003), Johnson et al. (2002) find that auditing and financial reporting, and audit firms' tenure have a positive relationship, so that the results of the research do not support mandatory auditor rotations. Geiger and
Raghunandan (2002) find evidence that auditors may be influenced by clients which they had in previous years, and do not support the arguments that propose mandatory auditor rotation. Myers et al. (2003) say that they do not find any evidence that supports the perception that low quality audits are related to long tenures by the auditor. Knechel and Vantraelen (2007) find evidence that there is no market reaction to auditors' tenure and switching, whereas the auditors' independence is not hampered by the duration of the relationship between the auditor and their client.

Lim and Tan (2010) show that the quality of the audits carried out for companies by professional auditors are higher than those by non-professional ones, when the auditor's tenure is longer. Furthermore, the increase in the audit's quality with a long tenure is higher, if the auditor has a lower audit fee range than the client. If a professional auditor for certain industries has to be rotated, there may be no other choice for companies other than to have to hire a non-professional auditor, which potentially decreases the audit's efficiency and effectiveness (Knechel et al. 2007).

Chi et al. (2009) and Siregar (2011) do not find that mandatory auditor rotations increase an audit's quality. They have studied audit data from Taiwan, with a rotation period of five years, which became mandatory in 2004. It is not mentioned that they also found no consistent evidence that supports the conviction that mandatory audit firms' rotation based on investor perceptions increases the audit's quality.

The supporters of rotation show that an audit's quality will increase as a result of the decreasing familiarity with the client (Nagy 2005). Furthermore, Jennings et al. 
(2006) using an experimental study approach analyzing the opinions of 49 judges that attended an advanced course at the National College Yuditial, perceived that evidence regarding auditors' independence can be increased by strengthening the audited companies' governance and auditor rotation. Furthermore, Fargher and Liwei (2008) find evidence that at the start of a period of tenure, the quality of the accounting policy decreases, but when there is a rotation, the quality of the accounting policy increases. Mandatory auditor rotations are based on 2 assumptions: (1) Long relationships between the auditor and client will interfere with the auditor's independence, and influence his/her capability for being neutral and objective, and (2) mandatory auditor rotation will overcome problems (if they exist) related to the long relationship between the auditor and the client (Jones, 2012).

Yurianto (2009) explains that generally, in day-to-day practice, the Decree of the Minister of Finance No.17/PMK.01/2008 creates tricky situations for both audit firms and their partners to exchange partners. For this business, an auditor may change his name to maintain and audit the same client. The name change appears to show that the auditor has been rotated, as per the regulation, even though in reality, the switch of auditors is considered to be an artificial rotation, since the client is still in the same relationship with the auditor who has just changed his name. This long period of association between the auditor and client can destroy the auditor's independence. Long auditor tenures may cause over-familiarity between the client and auditor (Mautz and Sharaf, 1961). Based on the concept and the results of previous researches, a second hypothesis can be formulated as follows:
Hypothesis 2: Auditor rotation has a positive influence on the auditor's independence.

\section{Methods}

\section{Population and Sample}

The population used in this research are auditors working in companies that are listed on the Indonesian Stock Exchange. The samples were chosen by using the purposive sampling method. Further, the sample selection process based on the criteria above is explained as shown in Table 1.

\section{Research Model}

The research model measures the effects of auditor tenure and auditor rotation on the tendency of the auditor to give a 'going concern' opinion by considering some control variables as Equation 1:

$$
\begin{aligned}
& \operatorname{Ln}\left[\frac{I N D}{1-I N D}\right]=\mathrm{a}+\mathrm{b}_{1} \text { TENURE }+ \\
& \mathrm{b}_{2} \text { ROTATION }+\mathrm{b}_{3} \text { REPUTATION }+ \\
& \mathrm{b}_{4} \text { LSIZE }+\mathrm{b}_{5} \text { AGE }+ \text { e....................... }
\end{aligned}
$$

Notation:

IND:

Independence as a dummy variable, 1 shows independent, 0 shows not independent.

TENURE: The relationship periods between auditor and client which substantively happen, measured in years.

ROTATION: Dummy variable, 0 means no rotation, and 1 means auditor rotation.

REPUTATION: The size of the auditor, which are differentiated 
Table 1. Sample Selection Process

Description

Companies published financial reports in 2002-2010

Companies with incomplete data

Companies published successive financial reports in 2002-2010 with

complete data

Companies without auditor rotation

Companies with real auditor rotation (the auditor was changed/

switched with another new one and the affiliation was changed as well)

Companies with artificial auditor rotation (the auditor changed their name and

the affiliation kept going)

Companies audited by an auditor in a certain period of time, after a 1 year

break the companies were audited by the same auditor.

Total company samples
Amount

2,809

962

1,847

Note: ${ }^{*}$ ) artificial rotation

into auditor with big 4 affiliated (given 1) and auditor with non-big 4 affiliated (given 0).

LSIZE: Logarithm of total assets.

AGE: The ages of the companies, which are measured in years.

a: $\quad$ Constants

b1,b2,b3,b4,b5: Coefficients

e: $\quad$ Error

\section{Definition of Variable Operational}

This research tests the effects of the auditor's tenure and rotation on their independence in cases where a 'going concern' opinion is given. The variables which are measured consist of the dependent and independent variables. The definition of the operational and all the research variables' measurements are explained below.

\section{Dependent Variable}

The dependent variable for this research model is independence. This variable is shown by the matrix $2 \times 3$ as shown in Table 2 .

The opinion, which is given by the auditor, is divided into two, they are the 'going concern' opinion and the 'non-going concern' opinion. The probability of a company facing financial problem(s) is measured by using the revised Z-Score Altman model (2000), in which $\mathrm{Z}=6.56$ WCTA + 3.26 RETA + 6.72 EBITTA + 1.05 BVETL + e. If the value of the Z-Score is less than 1.1, it is predicted that the company is likely to be bankrupt (in a 'distress' area), which is then 
Table 2. Matrix of the Relation between Financial Condition and Auditor Opinion

\begin{tabular}{|c|c|c|}
\hline Financial Condition & Audi & jinion \\
\hline & $\begin{array}{c}\text { GCO ('Going Concern' } \\
\text { Opinion) }\end{array}$ & $\begin{array}{c}\text { NGCO ('Non-Going Concern' } \\
\text { Opinion) }\end{array}$ \\
\hline Distress & I (Independent) & NI (Not Independent) \\
\hline Grey Area & $\mathrm{I}$ & $\mathrm{I}$ \\
\hline Non Distress & NI (Not Independent) & I \\
\hline
\end{tabular}

$\begin{array}{ll}\text { Notation: } & \\ \text { Distress. } & \text { Companies which faced financial problems } \\ \text { Grey Area: } & \text { Cannot determine whether companies are run well or face financial problems } \\ \text { Non Distress: } & \begin{array}{l}\text { Companies which did not face any financial problems based on the Altman method } \\ (2000) .\end{array} \\ \text { GCO: } & \text { 'Going concern' opinion given by the auditor } \\ \text { NGCO: } & \text { 'Non-going concern' opinion given by the auditor } \\ \text { NI: } & \text { Not an independent auditor } \\ \text { I: } & \text { Independent auditor }\end{array}$

given the value of 1 . If the Z-Score is between 1.1 and 2.6, it is predicted that the company did not have any guarantee of their financial condition always being stable (in a 'grey' area), which is given the value of 2 . If the Z-Score is more than 2.6 it is predicted that the company is not likely to go bankrupt (in a 'safe' area), which is then given the value of 3 .

When the condition of a company is in 'distress', it supposes that their auditor gives them a 'Going Concern' Opinion (GCO). If the auditor does not give a GCO, it can be concluded that the auditor is not independent. Another scenario for the auditor to be judged as not independent is that when the condition of a company is not in 'distress', the auditor gives a GCO. On the other hand, if a company is in a 'Distress' (D) condition and the auditor gives it a GCO, it can be concluded that the auditor is independent. Another scenario for the auditor to be judged as independent is that when a company is not in a 'distress' condition, the auditor gives a NGCO. The last but not least scenario is that if a company is in a 'Grey' Area (GA) condition and the auditor gives either a GCO or NGCO, it can be concluded that the auditor is independent.

\section{Independent Variable}

\section{Auditor Tenure}

The variable of the auditors' tenure shows the duration of the relationship between an auditor and client, which is measured in years. Although an auditor's tenure is measured by the number of years, as per the research by Myers et al. (2003) and Ghosh 
and Moon (2005), there is a difference with this research and the previous studies. Myers et al. (2003) and Ghosh and Moon (2005) measured the tenure by the number of years the relationship between the auditor and client existed in formal terms, whereas, in this research, the auditors' tenure is measured based on the duration of the relationship between the auditor and client in substantive terms, by considering the existence of any artificial auditor rotations.

\section{Auditor Rotation}

The second independent variable is auditor rotation which shows that there has been a change/switch of auditor done by the client, either voluntarily or mandated by regulations/law. The rotation variable is a dummy variable, where q shows that there has been an auditor rotation, and 0 shows that there is no rotation.

Furthermore, it can be seen that there exist artificial auditor rotations. Artificial rotations show that it seems there has been some sort of auditor rotation but in fact the relationship between the auditor and the client is still ongoing. Artificial rotation is done using the following methods: a. The audit firm changes its name (the name of a partner is changed in some way), and the firm's affiliations are kept going.

b. The audit firm changes its name (all the partners' names are changed) and the firm's affiliations are kept going.

c. The auditor who audits a client is changed/ switched for another auditor, but after one year goes by, the first auditor resumes auditing the original client.

\section{Control Variable}

This research uses some control variables to control the factors which may influence an auditor's independence as per the research by Carey and Simnett (2006) and Knechel and Vanstraelen (2007). Those are the auditor's reputation, the company's size, and the company's age.

\section{Analysis of the Results}

\section{Descriptive Statistics}

Descriptive statistics for each variable can be explained by the Table 3 . Table 3 explains that the total number of company

Table 3. Descriptive Statistics of Company Samples

\begin{tabular}{lccccc}
\hline Variable & $\mathbf{N}$ & Minimum & Maximum & Average & $\begin{array}{c}\text { Standard } \\
\text { Deviation }\end{array}$ \\
\hline Rotation & 1,847 & 0 & 1 & 0.30 & 0.457 \\
Tenure & 1,847 & 1 & 13 & 3.75 & 2.607 \\
Age & 1,847 & 2 & 95 & 28.90 & 14.658 \\
Reputation & 1,847 & 0 & 1 & 0.54 & 0.498 \\
Logarithm of total assets & 1,847 & 5 & 16 & 100.54 & 1.899 \\
Independence & 1,847 & 0 & 1 & 0.70 & 0.458 \\
\hline
\end{tabular}


samples in this research is 1,847 . The variables consist of five independent variables: Rotation, tenure, age, reputation, and the logarithm of total assets, and one dependent variable, independence. The rotation variable is a categorical variable with a minimum variable value of 0 , and a maximum of 1 , with a standard deviation of 0.457 . The tenure variable shows the duration of the unification between the auditor and client, which has a minimum value of 1 year and a maximum value of 13 years, with an average value of 3.75 years and a standard deviation of 2.607. The variable of the companies' ages shows a minimum value of 2 years and a maximum value of 95 years with an average value of 28.90 years and a standard deviation of 14.658. The reputation variable is a dummy

Table 4. Descriptive Statistics of Company Samples' Tenure

\begin{tabular}{|c|c|c|c|}
\hline Tenure & Frequency & Percentage & $\begin{array}{l}\text { Cumulative } \\
\text { Percentage }\end{array}$ \\
\hline 1 & 412 & 22.3 & 22.3 \\
\hline 2 & 350 & 18.9 & 41.3 \\
\hline 3 & 280 & 15.2 & 56.4 \\
\hline 4 & 209 & 11.3 & 67.7 \\
\hline 5 & 167 & 9.0 & 76.8 \\
\hline 6 & 134 & 7.3 & 84.0 \\
\hline 7 & 95 & 5.1 & 89.2 \\
\hline 8 & 77 & 4.2 & 93.3 \\
\hline 9 & 62 & 3.4 & 96.7 \\
\hline 10 & 25 & 1.4 & 98.1 \\
\hline 11 & 19 & 1.0 & 99.1 \\
\hline 12 & 16 & 0.9 & 99.9 \\
\hline 13 & 1 & 0.1 & 100.0 \\
\hline Total & 1,847 & 100.0 & \\
\hline
\end{tabular}

variable which has a minimum value of 0 , a maximum value of 1 , and a standard deviation of 0.498 . The variable of the logarithm of total assets shows a minimum value of 5 , a maximum value of 16 , an average value of 10.54 and a standard deviation of 1.899 . Furthermore, the independence variable is a categorical variable with a minimum value of 0 , a maximum value of 1 , and a standard deviation of 0.458 .

Table 4 shows that from all the samples, as many as 23.3 percent have more than 5 years of tenure, and the remaining 76.7 percent have less than 5 years of tenure. It means that although there has been a rotation, tenure is substantively still ongoing. From Table 4 , it appears that the shortest tenure is 1 year and the longest is 13 years.

Table 5. Descriptive Statistics of Auditor Tenure

\begin{tabular}{lcc}
\hline Rotation & Frequency & Percentage \\
\hline No auditor rotation & 1,298 & 70.3 \\
Auditor rotation & 549 & 29.7 \\
\hline Total & 1,847 & 100.0 \\
\hline
\end{tabular}

Table 6. Descriptive Statistics of Independence

\begin{tabular}{lcc}
\hline Independence & Frequency & Percentage \\
\hline Notindependent & 551 & 29.8 \\
Independent & 1,296 & 70.2 \\
Total & 1,847 & 100.0 \\
\hline
\end{tabular}


The rotation variable can be seen in Table 5, during the period from 2002-2010 there had been 549 auditor rotations. The de-

Table 7. Multicolinearity Testing

\begin{tabular}{lcc}
\hline & \multicolumn{2}{c}{ Colinearity Statistic } \\
\cline { 2 - 3 } Variable & Tolerance & VIF \\
\hline Tenure & 0.963 & 1.038 \\
Rotation & 0.905 & 1.105 \\
Age & 0.951 & 1.051 \\
Reputation & 0.895 & 1.117 \\
Logarithm of & & \\
total assets & 0.931 & 1.074 \\
\hline
\end{tabular}

Table 8. Capability of the Models to Classify Independence

\begin{tabular}{lccc}
\hline \multirow{2}{*}{ Observation } & \multicolumn{2}{c}{ Independence } & Percentage \\
\cline { 2 - 3 } & $\begin{array}{c}\text { Not Inde- } \\
\text { pendent }\end{array}$ & $\begin{array}{c}\text { Inde- } \\
\text { pendent }\end{array}$ & \\
\hline Not Independent & 59 & 492 & 10.7 \\
Independent & 24 & 1,272 & 98.1 \\
Total percentage & & & 72.1 \\
\hline
\end{tabular}

scription of the independence variable can be seen in Table 6, from 2002-2010 there were 551 audits of firms which were indicated as not being independent, and 1,296 audits which were considered independent.

\section{Multicolinearity Testing}

Based on the test results shown in Table 7 , it is seen that the VIF values $<10$. Thus, it can be concluded that there is no multicolinearity problem with the research models.

\section{Capacity of Model Classification}

Table 8 shows the capacity of the models to classify the auditors' independence. In total, 72.1 percent of the models are able to correctly estimate the auditors' independence.

\section{Appropriateness of Logistic Regression Mode1}

The next step is assessing the appropriateness of the logistic regression model by using Hosmer and Lemeshow's goodness of fit testing. The results of the appropriateness testing show that the value of Hosmer and Lemeshow's goodness of fit is 0.397 . Because the value of significance is bigger than 0.05 ,

Table 9. Results of Logistic Regression Testing

\begin{tabular}{lcccc}
\hline Variable & B & S.E. & df & p-value \\
\hline Rotation ${ }^{*}$ ) & 1.001 & 0.112 & 1 & 0.000 \\
Tenure $\left.{ }^{*}\right)$ & -0.101 & 0.021 & 1 & 0.000 \\
Age & -0.001 & 0.004 & 1 & 0.748 \\
Reputation & -0.143 & 0.112 & 1 & 0.200 \\
Logarithm of total assets & -0.008 & 0.029 & 1 & 0.771 \\
Constant & 0.763 & 0.356 & 1 & 0.032 \\
Nagelkerke R Square is 0.07 & & & & \\
\hline
\end{tabular}

Notes: *) Tenure shows the duration of the relationship of the auditor in auditing the client, which is measured in years.

$\left.{ }^{* *}\right)$ Rotation is a dichotomy variable that shows the existence of rotation which is described by the value of 0 for no auditor rotation, and the value of 1 for auditor rotation. 
the logistic regression model is appropriate to be used for explaining the independence.

\section{Hypothesis Testing}

The testing of Hypotheses 1 and 2 supported the results of the logistic regression testing, as shown in Table 9.

Based on the summary, model testing shows the Nagelkerke R Square value is 0.07 . This indicates that the independent variable in the model can explain the dependent variables 7 percent of the time, and the rest is explained by other variables.

Hypothesis 1's testing was for the effects of tenure (the duration of the relationship between auditor and client) on their independence. The testing shows a significance value of 0.000 , with a coefficient of -0.101 . Thus, Hypothesis 1, which is explained statistically, is supported. This shows that the duration of the relationship between the auditor and client has negative effects on the auditor's independence. The results of the analysis show that the relationship between auditor and client over a long time period make the auditor tend to be less or not independent. There have been regulations on the limits of a relationship's duration between auditor and client, which is a maximum of 5 years. However, the descriptive statistic shows that 23.5 percent of tenures last more than 5 years. This shows that although there have been clear regulations on the period of the relationship between auditor and client, the auditors still look for chances to keep their relationships with their clients going, so this influences the auditors' independence.

This finding supports Knechel and Vanstraelen (2007), Carey and Simnett (2006), Giri (2011) and Junaidi et al. (2012) who show that there is a negative relationship between auditors' tenure and the tendency of the auditors to give 'going concern' opinions on the back of long tenures. As a result, the limitation of the relationship's duration between auditor and client is important since, over a long time period, the relationship can reduce the auditor's independence. Opinion giving is an important part of an auditor's job. Thus, as professionals, auditors must be able to show their commitment to maintaining their independence. The existence of limitations to the length of the relationship's duration between auditor and client is seen as an effort to maintain and improve the auditors' independence.

The regulations on auditors' rotation are expected to be applied effectively, to maintain the auditors' independence. Further, the second hypothesis' testing analyzes the effects of auditors' rotation on auditors' independence. The analysis shows the significance value is 0.000 with a positive direction (a coefficient of 1.001). This indicates that the hypothesis which states that auditor rotations positively influence auditors' independence is statistically supported.This study's findings differ from Siregar et al. (2011) who found no evidence that longer auditors' tenures and auditors' rotations increased the quality of audits.

This is in line with the first hypothesis, that the lengthy duration of the relationship between an auditor and his/her client can reduce the auditor's independence. Therefore, rotation can increase the audit's quality since a long relationship can reduce the auditor's independence, considering the familiarity between the auditor and client. Even though there are debates on whether or not the regulation about rotation is important, this writer thinks that such a regulation is still needed, considering that, as professionals, accountants surely have to maintain their quality and independence. 


\section{Sensitivity Analysis}

This research also includes some sensitivity testing to check for the robustness of the main model's testing.

Sensitivity Test on the Effect of the Types of Auditor Rotations on Auditors' Independence.

This test is done to see the effect of auditor rotations on auditors' independence. The types of rotations are divided into two: An artificial auditor rotation and a non-artificial auditor rotation. The analysis shows a p-value of 0.000 and a coefficient value of 1.796. This indicates that artificial rotation has significant negative effects on the auditors' independence. This finding supports the first hypothesis which states that auditors' tenure has negative effects on auditors' independence. It means, even though there is a rotation, the relationship between the audi- tor and the client does not end, so that this ongoing relationship can interfere with the auditor's independence.

\section{The Effects of Auditor Tenure on Auditors' Independence in Each Industry}

The effects of auditors' tenure on auditors' independence in each industry can be seen in Table 10.

The tenure is divided into short tenure and long tenure. Short tenure means the maximum period of the relationship between auditor and client is 5 years, and long tenure means the relationship lasted more than 5 years. Table 10 shows that the types of companies which are most likely to have long tenure and whose auditors are not independent are manufacture companies, numbering 67 , whereas companies with long tenure but have independent auditors is also manufacture companies, which number 174.

Table 10. The Effects of Auditor Tenure on Auditors' Independence in Each Industry

\begin{tabular}{lcccc}
\hline & \multicolumn{2}{c}{ Not independent } & \multicolumn{2}{c}{ Independent } \\
\cline { 2 - 5 } Industry & $\begin{array}{c}\text { Long Tenure } \\
\text { Amount }\end{array}$ & $\begin{array}{c}\text { Short Tenure } \\
\text { Amount }\end{array}$ & $\begin{array}{c}\text { Long Tenure } \\
\text { Amount }\end{array}$ & $\begin{array}{c}\text { Short Tenure } \\
\text { Amount }\end{array}$ \\
\hline Agriculture & 2 & 5 & 4 & 25 \\
Animal feed & 3 & 2 & 3 & 10 \\
Mining & 0 & 2 & 4 & 30 \\
Construction & 0 & 0 & 3 & 6 \\
Manufacturing & 67 & 134 & 174 & 535 \\
Transportation & 7 & 16 & 20 & 20 \\
Communication & 2 & 4 & 2 & 10 \\
Wholesale \& retail & 6 & 7 & 19 & 49 \\
Banks, Credit agency, Securities, & & 197 & 29 & 245 \\
Insurance, Real estate & 54 & 5 & 7 & 18 \\
Hotels \& travel services & 3 & 27 & 11 & 72 \\
Others & 8 & & &
\end{tabular}


The Effects of Auditor Rotation on Auditors' Independence in Each Industry

This test is carried out to see the effects of auditor rotations on auditors' independence, in this case it is tested on companies with rotations and companies without rotations.

Table 11 shows that the greatest number of companies that have rotation and whose auditors are independent is again the manufacture companies, numbering 148.

The next test is done to see the effects of the type of rotation on the auditors' independence in each industry. There were 549 rotations during our observation period. Table 11 describes that artificial rotations without independent conditions occurred in the bank- ing, credit agency, securities, insurance, and real estate industries, amounting to 26 instances, whereas artificial rotations with independent conditions occurred in manufacture industries as 116.

Table 13 shows that artificial rotations occurring after more than 5 years tenure amounted to 89 rotations, and in less than 5 years tenure they numbered 163 rotations.

Table 14 explains the relationship between the type of rotation and the auditors' reputation. Based on Table 14, it can be seen that auditors who have affiliations with big 4 and have done an artificial rotation amount to 155 , whereas auditors who have affiliations with non-big 4 auditors and have done an artificial rotation number 97 .

Table 11. The Effect of Auditor Rotation on Auditors' Independence in Each Industry

\begin{tabular}{lcccc}
\hline & \multicolumn{2}{c}{ Not independent } & \multicolumn{2}{c}{ Independent } \\
\cline { 2 - 5 } Industry & $\begin{array}{c}\text { No rotation } \\
\text { Amount }\end{array}$ & $\begin{array}{c}\text { Rotation } \\
\text { Amount }\end{array}$ & $\begin{array}{c}\text { No rotation } \\
\text { Amount }\end{array}$ & $\begin{array}{c}\text { Rotation } \\
\text { Amount }\end{array}$ \\
\hline Agriculture & 2 & 5 & 23 & 6 \\
Animal feed & 2 & 3 & 12 & 1 \\
Mining & 0 & 2 & 22 & 12 \\
Construction & 0 & 0 & 6 & 3 \\
Manufacture & 94 & 107 & 561 & 148 \\
Transportation & 12 & 11 & 35 & 5 \\
Telecommunication & 3 & 3 & 10 & 2 \\
Wholesale \& retail & 4 & 9 & 55 & 13 \\
Banks, Credit agency, Securities, & 171 & 80 & 181 & 93 \\
Insurance, Real estate & 6 & 2 & 18 & 7 \\
Hotels \& travel services & 17 & 18 & 64 & 19 \\
Others & & & & \\
\hline
\end{tabular}


Table 12. The Effects of Rotation Type on Auditors' Independence in Each Industry

\begin{tabular}{|c|c|c|c|c|}
\hline \multirow[b]{3}{*}{ Industry } & \multicolumn{2}{|c|}{ Not independent } & \multicolumn{2}{|c|}{ Independent } \\
\hline & $\begin{array}{l}\text { Artificial } \\
\text { Rotation }\end{array}$ & $\begin{array}{l}\text { Non-Artificial } \\
\text { Rotation }\end{array}$ & $\begin{array}{l}\text { Artificial } \\
\text { Rotation }\end{array}$ & $\begin{array}{l}\text { Non-artificial } \\
\text { Rotation }\end{array}$ \\
\hline & Amount & Amount & Amount & Amount \\
\hline Agriculture & 0 & 0 & 5 & 6 \\
\hline Animal feed & 2 & 0 & 1 & 1 \\
\hline Mining & 0 & 0 & 3 & 11 \\
\hline Construction & 0 & 0 & 0 & 3 \\
\hline Manufacture & 14 & 23 & 116 & 102 \\
\hline Transportation & 6 & 1 & 7 & 2 \\
\hline Telecommunication & 2 & 0 & 1 & 2 \\
\hline Wholesale \& retail & 3 & 2 & 7 & 10 \\
\hline $\begin{array}{l}\text { Banks, Credit agency, Securities, } \\
\text { Insurance, Real estate }\end{array}$ & 26 & 37 & 38 & 71 \\
\hline Hotels \& travel services & 2 & 0 & 3 & 4 \\
\hline Others & 6 & 4 & 10 & 17 \\
\hline
\end{tabular}

Table13. Relation between Rotation and Tenure

\begin{tabular}{lcc}
\hline & \multicolumn{2}{c}{ Tenure } \\
\cline { 2 - 3 } Rotation type & $\begin{array}{c}\text { >5 years } \\
\text { Amount }\end{array}$ & $\begin{array}{c}\text { × 5 years } \\
\text { Amount }\end{array}$ \\
\hline Artificial & 89 & 163 \\
Real & 18 & 279 \\
\hline
\end{tabular}

Table 14. The Relation between Rotation Type and Auditors' Reputation

\begin{tabular}{lcc}
\hline & \multicolumn{2}{c}{ Type of Rotation } \\
\cline { 2 - 3 } & Artificial & Real \\
\cline { 2 - 3 } Auditor's Reputation & Amount & Amount \\
\hline Non big 4 & 97 & 201 \\
Big 4 & 155 & 95 \\
\hline
\end{tabular}




\section{Control Variable Testing}

The control variable is a variable which is controlled or made constant so that the relationship of the independent variable towards the dependent variable is not influenced by external factors which have not been studied. There are three variables which are put into the companies in our study: The company's size, their auditor's reputation, and the company's age. The company's size shows a significance level of 0.866 which means this variable does not influence auditors' independence, measured by them giving a 'going concern' opinion. This case is different from the research of Mutchler et al. (1997), and Knechel and Vanstraelen (2007), which stated that an auditor who gives a 'going concern' opinion is inversely proportional to the size of their client's company.

The age variable shows a significance level of 0.694 . Thus, the age variable statistically does not influence the independence. This finding supports the results of research done by Knechel and Vanstraelen (2007) and contradicts the research of Carey and Simnett (2006) which stated that the age variable is inversely proportional to the tendency of getting a 'going concern' opinion. Older companies tend to be able to adapt better to the conditions of their business' environment. Experienced managers of these companies will be able to anticipate any financial problems that may influence the audit's quality.

The auditors' reputation variable shows a significance value of 0.219 . This means that, statistically, the reputation variable does not significantly influence an auditor's independence. This is related to the quality of the auditing carried out, and the audit firm, whether it is big or small, which does not have any difference on the quality of the audits it conducts. Big and small auditor firms will maintain their quality, based on the Professional Public Accountants' Standards. This is different to the research done by Mutchler, et al. (1997), Francis and Yu (2009) and DeFond et al. (2002) which found that the larger firms of auditors were more likely to give 'going concern' opinions.

\section{Result and Policy Implication}

Based on the analysis, the logistic regression shows that tenure has a negative effect on an auditor's independence. There are some significant differences between the effects of a short tenure and the effects of a longer tenure on the auditor's independence. Those results are supported by a sensitivity test which shows that tenures of up to 6 years have negative effects on auditors' independence. This gives the implication that over a long period, an auditor-client relationship can reduce the auditor's independence. For that, regulation on the duration of the relationship between auditor and client must effectively enforce the limitations of auditors' tenure.

The government has published the Decree of the Minister of Finance No.423/ KMK.06/2002, which was superseded by the Decree of the Minister of Finance No.359/ KMK.06/2003, which obliged companies to limit an auditor's assignment period to 5 years and a public accountant's to 3 years. That decree then was revised by the Decree of the Minister of Finance No.17/PMK.01/2008 about public accountants' service which set the limit of the auditors' assignment period at 6 years and public accountants' at 3 years. Based on the results of this research, the effectiveness of the auditors' tenure regulation of 6 years needs to be reconsidered, since auditor tenures of up to 6 years have negative effects on auditors' independence. In other words, since long tenures can decrease 
auditors' independence, the regulation on auditors' tenure should be for a maximum of 5 years, or less. This limitation to 5 years is in line with Law No.5 of 2011 about public accountants. In relation to the regulation on public accountants' service rotation, it is written in Article 11 PP 20/2015 in which Article 11 Verse (1) explained that: The service of auditing historical financial information as per what is meant in Article 10 Verse (1) letter " $a$," to a certain entity by a public accountant is limited to be at most only 5 (five) years financial records in succession.

Until today, the regulation on auditors' rotation is only effective for local auditors, whereas there is no regulation about foreign auditors' rotations. Practically, this regulation can be bypassed by employing an artificial rotation of auditors, in which the auditors only change their names. Thus deeper consideration about regulating the rotations is really needed. If the assumptions given in this research are right, that basically auditors do not want to lose their clients, and auditors' tenures are reduced (a maximum of 5 years), there will be an equalization of income for the audit firms, without neglecting their quality. It can be concluded that instead of the regulation on auditors' rotation being bypassed so easily, it would be better if the government regulates the partners in audit firms' rotations. This is in line with the newest regulation on the rotation of public accountants as presented in Article 11 of Government Regulation 20/2015.

\section{Research Findings}

Auditor's independence is still an interesting topic to be studied by empirical research. If the assumptions used in this research are right, that basically auditor firms do not want to lose their clients and their potential fees, it means that independence becomes a very crucial thing, even though the effects of audit fees on the quality of audits have not been conclusive. In other words, the effects of tenure on an audit's quality can be biased towards the company's size, since big companies are assumed to be more complex, so that the potential fees will be higher. Another finding is that artificial rotations substantially cause auditors' relationships with their clients to be maintained. As a result, it can be concluded that the regulation for mandatory auditors' (client) rotation are needed.

\section{Conclusions, Limitations, and Suggestions}

Nowadays, it is considered that the quality of the audits being carried out has dropped, since there are many suspected factors that influence the quality. Auditor tenure is a factor that may interfere with an auditor's independence, considering that over a long time period there can be over-familiarity between the client and auditor. The phenomenon of the artificial rotations occurring in Indonesia is interesting and worthy of deeper study considering the regulation for mandatory auditors' rotation that has been published by the government. Artificial rotation shows a condition in which, theoretically, there has been a change of auditor, so that the relationship between the audit firm and the client ends, but in fact the relationship is still ongoing. The relationship between auditor and client over a long period of time can interfere with the auditor's independence.

Artificial auditor rotation is also worth further study since the relationship between auditor and client over a long period of time is also suspected to interfere with the 
auditor's independence. The results of this study show that the duration of the relationship between the auditor and client has negative effects on the auditor's independence. That kind of long term relationship can make the auditor less independent. The results of the sensitivity analysis show that there are significant differences between the effects of a short tenure and long tenure on auditors' independence.

Auditor rotation significantly influences auditors' independence. The positive direction of this result shows that auditor rotation can maintain an auditor's independence. This result implies that auditor rotation is important since a long relationship between the auditor and their client can influence the auditor's independence. Furthermore, sensitivity analysis shows that artificial auditor rotation has negative effects on the auditors' independence. This indicates that the thinking behind artificial rotation needs to be given further attention, especially by the auditors' regulatory body. The regulation of auditors' rotations is important and must be able to be enforced effectively in practice. What needs to be avoided are auditor rotations which are done for the sake of fulfilling the regulation, but which neglect the fact that there is a bigger need to be maintained, which is the auditors' independence, to boost the quality of the audits they carry out. This finding confirms the concept of independence, in that an auditor has to possess a strong mental attitude to not take any side when auditing.

\section{Limitations}

The research into the effects of auditors' tenure on auditors' independence, which is measured by their giving 'going concern' opinions does not include data from companies which faced financial problems, or were declared bankrupt. Furthermore, the period of observation is also limited, starting from 2002 up to 2010, because after the year 2008, the regulation for the relationship period between auditor and client was changed. This research focuses only on companies which were listed on the Indonesian Stock Exchange, whereas there many other mediumand small-scale companies that could be included in the research.

One of the artificial auditor rotation measurements uses the assumption that, after a grace period of 1 year from the end of the first relationship period, the client will be audited by the same audit firm, but in fact the firm that actually does the audit is the previous audit firm. The researcher faced some difficulties in collecting evidence about the auditors who carried out the audits in that 1 year grace period.

Independence is measured by seeing the relationship between the results of the auditors' stated opinions and the financial condition of the audited companies. This research does not include companies which were considered to be doubtful of remaining as a ' $\mathrm{go}$ ing concern' and which were then made bankrupt. Although statistically, an auditor's tenure has significant negative effects on the auditor's independence, theoretically it has not been proven, as the results of research which tested those issues have not been conclusive.

\section{Suggestions}

Future research could be done into the same topic, but with different measurements of the audits' quality, such as fraud and the financial reports' quality. Besides, future research can include the fee variable as one of the indicators that may influence an audit's quality. Future researches can also be done 
using the same approach, by extending the duration of the observation period and widening the sample to include not only companies that are listed on the Indonesian Stock Exchange, but also those which are not listed.
Besides this, the study into tenure can be broadened by testing the duration of the relationship of the audit firms' partners and clients.

\section{References}

AICPA. 1988. The Auditor's Consideration of an Entity's Ability to Continue as a Going Concern (SAS No. 59). http://aicpa.org/research/standards/auditattest/pages/sas.aspx.

Altman, E. I., and T. P. McGouch. 1974. Evaluation of a company as a going concern. The Journal of Accountanc: :50-57

Altman, E. I. 2000. Predicting financial distress of companies: Revisiting the z-score and zeta models. http://pages.stern.nyu.edu/ ealtman/ PredFnclDistr.pdf

Altman, E. I.. 2009. Current Condition in Global Credit Markets: A Tale of Three Periods. NYU Stern School of Business

Al-thuneibat, A. A., R. T. Ibrahim Al Isa, and R. A. Ata Baker. 2010. Do audit tenure and firm size contribute to audit quality?.Managerial Auditing Journal vol. 26 no. 4: 317-334.

Bazerman, M. H., K. P. Morgan, and G. F. Loewanstein. 1997. The impossibility of auditor independence. Sloan Management Review 38 (Summer): 89-94.

Carmichael, D. R., and K. Pany. 1993. Reporting on uncertainties, including going concern. In The Expectation Gap Standards: Progress, Implementation Issues, Research Opportunities, 35-58. New York, NY: AICPA.

Carcello, J. V., and T. L. Neal. 2000. Audit committee composition and auditor reporting. The Accounting Review 75 (4): 453-467.

Carcello, J. V., and Albert L. Nagy. 2004. Audit firm tenure and fraudulent financial reporting. Auditing: A Journal of Practice and Theory 23 (2): 55-69.

Carey, P., and R. Simnett. 2006. Audit partner tenure and audit quality. The Accounting Review 81 (3): 653676.

Chi, W., H. Huang, Y. Liao, and H. Xie. 2009. Mandatory audit partner rotation, audit quality, and market perception: Evidence from Taiwan. Contemporary Accounting Research 26 (2): 359-391.

Chow, C. W., and S. J. Rice. 1982. Qualified audit opinions and auditor switching. The Accounting Review 57 (April): 326-335.

Chow, C. W., A. H. McNamee, and R. D. Plumlee. 1987. Practitioners' perceptions of audit step difficulty and criticalness: Implications for audit research. Auditing: A Journal of Practice and Theory 6 (Spring): 123-133.

Coram, Paul, Alma, Glavovic, Ng Juliana, and David R. Woodliff. 2008. The moral intensity of reduced audit quality acts. Auditing 27 (1): 127-149

Daugherty, B. E., D. Dickins, R. C. Hatfield, and J. L. Higgs. 2012. An examination of partner perceptions of partner rotation: Direct and indirect consequences to audit quality. Auditing: A Journal of Practice and Theory 31 (1): 97-114. 
Daugherty, B. E., D. Dickins, R. C. Hatfield, and J. L. Higgs. 2013. Practitioner summary mandatory audit partner rotation: Perceptions of audit quality consequences. Current Issues in Auditing 7 (1): 30-35

Daugherty, B. E., D. Dickins, J. Higgs, and K. Tatum. 2013. The question of mandatory audit firms' rotation: Would investors benefit? The CPA Journal: 28-33.

Davis, L. R., D. N. Ricchiute, and G. Trompeter. 1993. Audit effort, audit fees, and the provision of audit services to audit clients. The Accounting Review 68 (January): 135-150.

Davis, L. R., B. Soo, and G. Trompeter. 2002. Audit tenure, auditor independence and earnings management. Working paper. Boston College, Boston, MA.

Davis, R. R.2009. Financial ratio influencing the issuance of auditor's going concern opinions. Northest Business and Economics Association proceedings (January).

DeAngelo, L. E. 1981 a. Auditor independence, low balling, and disclosure regulation. Journal of Accounting and Economics: 113-127.

DeFond, M. L., K. Raghunandan, and K. R. Subramanyam. 2002. Do non-audit service fees impair auditor independence? Evidence from 'going concern' opinion decisions. Journal of Accounting Research (June): 1247-1274.

Deis Jr.,, D. R., and G. A. Giroux.1992. Determinants of audit quality in the public sector. The Accounting Review 67 (3) (July): 462-479.

Dharmasaputra, M., and M. Nafi. 2007. Jerat baru para auditor. Tempo Weekly Magazine 04 (16).

Fargher, N. L., and J. Liwei. Changes in the audit environment and auditors' propensity to issue 'going concern' opinions. Auditing 27 (2): 55-77

Francis, J., and M. Yu. 2009. The effect of big four office size on audit quality. The Accounting Review 84 (5): 1521-1552.

Geiger, M. A., and K. Raghunandan. 2002. Auditor tenure and audit reporting failures. Auditing: Ajournal of Practice and Theory 21 (1): 67-78.

Geiger, M. A., and D. V. Rama. 2006. Audit firm size and 'going concern' reporting accuracy. Accounting Horizons 20 (1)1: 1-17.

Ghosh, Aloke, and DoocheolMoon. 2005. Auditor tenure and perceptions of audit quality. Journal of Business Finance and Accounting 80 (2): 209-247.

Giri, EfraimFerdinan. 2011. The effect of tenure and reputation of public accounting firms toward audit quality: Case for mandatory rotation. The Indonesian Journal of Accounting Research 14 (1): 1-19.

Hartadi, B. 2001. Analisis multivariate pada proses pembuatan keputusan pendapat kelangsungan usaha. Jurnal KOMPAK (1): 1-27.

Hartadi, B. 2009. Pengaruh fee audit, rotasi KAP, dan reputasi auditor terhadap kualitas audit di Bursa Efek Indonesia. Ekuitas: Jurnal Ekonomi dan Kenangan 16 (1): 84-103

Hoyle, J. 1978. Mandatory auditor rotation: The arguments and an alternative. Journal of Accountancy 145 (5): 69-78.

Ikatan Akuntan Indonesia (IAI). 2001. Standar Profesional Akuntan Publik. Jakarta: Salemba Empat.

Institut Akuntan Publik Indonesia (IAPI). 2009. Standar Profesional A kuntan Publik. Jakarta: Salemba Empat.

Junaidi, S. Miharjo, and B. Hartadi. 2012. Does auditor tenur reduce audit quality? Gadjah Mada International Journal of Business 14 (3):303-315. 
Johnson, E., I. K. Khurana, and J. K. Reynolds. 2002. Audit-firm tenure and the quality of financial reports. Contemporary Accounting Research 19 (4): 637-660.

Knechel, W. R., and A. Vanstraelen. 2007. The relationship between auditor tenure and audit quality implied 'going concern' opinions. Auditing: A Journal of Practice \& Theory 26 (1): 113-131.

Knechel, W. R., V. Naiker and G. Pacheco. 2007. Does auditor industry specialization matter? Evidence from market reaction to auditor switches. Auditing: A Journal of Practice and Theory 26 (1): 19-45.

Lasllae, R. E., and A. Anandarajan. 1996. Auditor View on The Type of Audit Report Issued to Entities with 'Going Concern.' Accounting Horizons 10: 51-72.

Lee, C. J., C. Liu, and T. Wang. 1999. The 150-hour rule. Journal of Accounting and Economics. 27 (2): 203-228.

Lim, C-Y., and H-T. Tan. 2010. Does auditor tenure improve audit quality. Contemporary Accounting Research 27 (1): 923-957.

Manry, D. L., T. J. Mock, and J. L. Turner. 2003. Does increased audit partner tenure reduce audit quality? Journal of Accounting, Auditing and Finance: 553-572.

Mai, D., S. Mishra, and K. Raghunandan. 2008. Auditor tenure and shareholder ratification of the auditor. Accounting Horizons 22 (3): 297-234

Mansi, S., W. Maxwell, and D. Miller. 2004. Does audit quality and tenure matter to investors? Journal of Accounting Research 23 (2): 17-30.

Mautz, R. K., and Hussein. A. Sharaf. 1961. The philosophy of auditing. American Accounting Association Monograph. Sarasota, Florida: American Accounting Assosiation.

Myers, J. N, L. A. Myers, and T. C. Omer. 2003. Exploring the term of auditor-client relationship and the quality of earnings: A case for mandatory auditor rotation? The Accounting Review 78 (3): 779-798.

Mutchler, J. F., W. Hopwood, and J. M. McKeown. 1997. The influence of contrary information and mitigating factors on audit opinion decisions on bankrupt companies. Journal of Accounting Research 35 (2): 295-310.

Menteri Keuangan. 2008. Peraturan menteri keuangan nomor: 17/pmk. 01/2008. tentang jasa akuntan publik. www.depkeu.go.id.

Peecher, M. E., and M. D. Piercey. 2008. Judging audit quality in light of adverse outcomes: Evidence of outcome bias and reverse outcome bias. Contemporary Accounting Research 25 (1): 243-274.

Shafie, R., W. N. Wan Hussin, M. A. Md. Yusof, and M. H. Hussain. 2009. Audit firm tenure and auditor reporting quality: Evidence in Malaysia. International Business Research 2 (2): 100-109.

Siregar, S. V., Fitriany, A. Wibowo, and V. Anggraita. 2011. Rotasi dan kualitas audit: Evaluasi atas kebijakan menteri keuangan KMK No.23/KMK.6/ 2002 tentang jasa akuntan publik. Jurnal Akuntansi dan Keuangan Indonesia 8 (1): 1-20

Yurianto, P. S. 2009. Peraturan menteri keuangan no. 17/pmk.01/2008: pemecahan masalah atau ilusi?. Kompak Jurnal Bisnis 16 (2): 147-157. 
